\title{
Sosialisasi Sistem Keselamatan Penumpang Angkutan Penyeberangan Bira-Pamatata
}

\author{
Sabaruddin Rahman*, Daeng Paroka, Achmad Yasir Baeda, Chairul Paotonan, Hasdinar Umar \\ Departemen Teknik Kelautan, Fakultas Teknik Universitas Hasanuddin \\ sabaruddin-r@eng.unhas.ac.id*
}

\begin{abstract}
Abstrack
KMP. Lestari Maju accident which occurred on 3 July 2018 resulted in the loss of life. The accident was caused by water rising to the deck of the vehicle due to high waves. The loss of life caused by a lack of understanding of passengers related to safety procedures on the ship during an accident. This is based on the results of the KNKT investigation which explains that passengers panicked and there was a struggle over rescuers so some passengers did not have time to wear life jacket. Whereas based on data on safety facilities on board, the number of life jackets is sufficient for the number of passengers onboard at the time of the accident. In addition, there were no instructions from the crew to jump into the sea so that the passengers saved themselves. Some even jump into the sea without wearing a life jacket. From the results of the KNKT investigation it was also found that the crew never carried out a safety drill, especially training in the safety of abandon ship. The lack of ISM Code implementation and supervision of the performance of the crew affected the lack of alertness of the crew at the time of accident. Through this activity, socialization of safety induction was carried out on the Bira-Pamatata ferry transportation facilities. Prior to the socialization, a survey was conducted to determine the condition of the existing safety devices on the ship and also to find out information that has not been accommodated in the safety procedures on the ship. Based on the results of a survey conducted, it is known that about $45 \%$ of respondents use the ferry transportation service no more than three times in the last two years. These respondents generally have a relatively low understanding of safety procedures on board. For this reason, the implementation must be carried out every ship leaving. Based on the evaluation results, the understanding of responsiveness tends to improve after the implementation of the socialization.
\end{abstract}

Keywords: Abandon ship; ferry; maintenance; safety induction; safety procedure.

\begin{abstract}
Abstrak
Kecelakaan KMP. Lestari Maju yang terjadi pada tanggal 3 Juli 2018 mengakibatkan jatuhnya korban jiwa. Kecelakan tersebut diakibatkan oleh air yang naik ke geladak kendaraan karena gelombang tinggi. Jatuhnya korban jiwa diakibatkan kurangnya pemahaman penumpang terkait prosedur keselamatan di atas kapal saat terjadi kecelakan. Hal ini didasarkan dari hasil penyelidikan KNKT yang menjelaskan bahwa penumpang panik dan terjadi perebutan jaket penolong sehingga beberapa penumpang tidak sempat mengenakan jaket penolong. Padahal berdasarkan data fasilitas keselamatan di atas kapal, jumlah jaket penolong mencukupi untuk jumlah penumpang yang ada saat terjadi kecelakaan. Selain itu, tidak ada instruksi dari awak kapal untuk terjun ke laut sehingga penumpang menyelamatkan diri masing-masing. Bahkan ada yang terjun ke laut tanpa mengenakan jaket penolong. Dari hasil investigasi KNKT tersebut pula ditemukan bahwa awak kapal tidak pernah melakukan pelaksanaan safety drill terutama pelatihan keselamatan orang meninggalkan kapal (abandon ship). Kurangnya penerapan ISM Code dan pengawasan terhadap kinerja awak kapal berimbas pada kurangnya kesigapan awak kapal pada saat terjadi kecelakaan. Melalui kegiatan ini dilaksanakan sosialisasi prosedur keselamatan di atas sarana angkutan penyeberangan Bira-Pamatata. Sebelum dilakukan sosialisasi, terlebih dahulu dilakukan survey untuk mengetahui kondisi eksisting alat keselamatan di atas kapal dan juga untuk mengetahui informasi yang belum terkomodir dalam prosedur keselamatan di atas kapal. Berdasarkan hasil survey yang dilaksanakan, diketahui bahwa sekitar $45 \%$ responden menggunakan jasa angkutan penyeberangan tidak lebih dari tiga kali dalam dua tahun terakhir. Responden tersebut umumnya memiliki pemahaman yang relatif rendah terhadap prosedur keselamatan di atas kapal. Untuk itu pelaksanaannya harus dilaksanakan setiap kapal akan berangkat. Berdasarkan hasil evaluasi, pemahaman responen cenderung memaik setelah dilakukan pelaksanaan sosialisasi.
\end{abstract}


Kata Kunci: Angkutan penyeberangan; meninggalkan kapal; pemeliharaan; pengenalan keselamatan; prosedur keselamatan.

\section{Pendahuluan}

Angkutan penyeberangan merupakan sarana vital bagi masyarakat di wilayah kabupaten Selayar yang menghubungkan pulau Sulawesi dan pulau Selayar. Angkutan tersebut dimanfaatkan untuk pergerakan barang maupun penumpang. Muatan barang diangkut menggunakan truk, sementara penumpang menggunakan bus. Muatan barang dan penumpang tersebut sebagian besar berasal dari Makassar. Selain itu, muatan angkutan penyeberangan juga berupa alat berat, kendaraan pribadi roda dua maupun roda empat.

Kecelakaan angkutan penyeberangan terjadi pada tanggal 3 Juli 2018 yang lalu. Kapal Lestari Maju dikandaskan di perairan Pabadilang kepulauan Selayar setelah mengalami kemiringan karena diterjang ombak setinggi 0,5 - 2,0 m. Kecelakaan tersebut mengakibatkan jumlah korban meninggal penumpang sebanyak 34 orang dan satu orang dikabarkan hilang dari total penumpang sebanyak 139 orang. Korban yang meninggal dikarenakan kepanikan penumpang memaksa mereka untuk mengambil keputusan melompat ke laut.

Adapun permasalahan yang dihadapi mitra saat ini yakni belum maksimalnya pelaksanaan pengenalan prosedur keselamatan bagi penumpang angkutan penyeberangan di atas kapal. Salah satu indikasi terlihat dari tidak dilakukannya perbaikan atau penggantian media sosialisasi yang sudah rusak. Untuk itu melalui kegiatan ini dilakukan sosialisasi prosedur keselamatan di atas laut pada penumpang angkutan penyeberangan. Melalui kegiatan ini pula dilakukan evaluasi dengan pembagian kuesioner untuk mengetahui pengaruh kegiatan sosialisasi terhadap pemahaman penumpang terkait prosedur keselamatan.

\section{Latar Belakang Teori}

Menurut Faturachman, et al. (2015), kecelakaan yang terjadi pada transportasi sungai, danau dan penyeberangan lebih disebabkan oleh faktor manusia. Untuk itu, pemahaman pengguna moda transportasi angkutan penyeberangan terkait sistem keselamatan di atas kapal sangat penting. Jumlah korban saat kecelakaan bisa dikurangi jika ada keinginan kuat dari semua pihak untuk meminimalkan resiko terjadinya kecelakaan. Pada kegiatan ini, pemahaman pengguna angkutan penyeberangan terkait beberapa fasilitas keselamatan di atas kapal akan dievaluasi untuk selanjutnya dilakukan sosialisasi pengenalan fasilitas tersebut.

Kapal roro digolongkan pada kapal tipe pelayaran pantai (short international voyage) karena jarak kurang dari 200 mil laut. Dengan demikian, peralatan yang dipersyaratkan dalam SOLAS sebagai minimum alat keselamatan yang harus dimiliki oleh sebuah kapal adalah life buoy, life jacket, inflatable life raft, sekoci penyelamatn (life boat), alat pelontar tali, pakaian cebur. Setiap pemilik bersama awak kapal diharuskan merawat peralatan keselamatan kapal. Berdasarkan Peraturan Pemerintah Republik Indonesia nomor 51 tahun 2002 tentang perkapalan pada pasal 71, (1) alat penolong di kapal harus dipelihara dan dirawat sesuai dengan persyaratan; (2) pemeliharaan dan perawatan jenis alat penolong tertentu yang memerlukan pemeliharaan dan perawatan di darat, harus dilakukan pada bengkel pemeliharaan dan perawatan yang diakui.

Berdasarkan peraturan menteri perhubungan nomor PM 39 tahun 2015 diatur terkait standar pelayanan penumpang angkutan penyeberangan di kapal diantaranya informasi penempatan dan 
tata cara penggunaan peralatan keselamatan saat sebelum kapal berangkat yang ditayangkan dalam bentuk visual dan/atau audio. Selain itu, penumpang harus mendapat penjelasan terkait dengan tindakan yang harus dilakukan saat terjadi keadaan darurat.

Setiap peralatan keselamatan harus diperiksa masa berlakunya. Peralatan telah habis masa berlakunya harus diganti untuk menghindari terjadi disfungsi peralatan yang justru akan menambah korban jiwa ketika kecelakaan kapal terjadi. Tabel 1 menunjukkan peralatan keselamatan yang harus tersedia di atas kapal yang mengangkut penumpang beserta jadwal perbaikan dan pembaharuannya.

Tabel 1. Alat keselamatan minimal di atas kapal yang mengangkut penumpang

\begin{tabular}{|l|l|}
\hline \multicolumn{1}{|c|}{ Nama alat } & \multicolumn{1}{|c|}{ Jadwal pemeliharaan dan penggantian } \\
\hline Liferaft & Pemeliharaan setiap tahun \\
\hline Lifejackets & $\begin{array}{l}\text { Pemeliharaan setiap tahun } \\
\text { Penggantian batterei lampu setiap lima } \\
\text { tahun }\end{array}$ \\
\hline Lifeboat & $\begin{array}{l}\text { Pemeriksaan permesinan, sistem } \\
\text { penggerak setiap tahun }\end{array}$ \\
\hline Hydrostatic release & Pemeliharaan setiap tahun \\
\hline $\begin{array}{l}\text { Rocket parachute flares } \\
\text { rockets) }\end{array}$ & $\begin{array}{l}\text { Diganti sesuai tanggal kadaluarsa dari } \\
\text { pabrik }\end{array}$ \\
\hline Red hand distress flares & Diganti setiap tiga tahun \\
\hline Emergency lighting & $\begin{array}{l}\text { Diperiksa setiap pelatihan orang } \\
\text { meninggalkan kapal }\end{array}$ \\
\hline Smoke signal & $\begin{array}{l}\text { Diganti sesuai tanggal kadaluarsa dari } \\
\text { pabrik }\end{array}$ \\
\hline EPIRB & $\begin{array}{l}\text { Pengujian setiap tahun } \\
\text { Penggantian batterei setiap lima tahun }\end{array}$ \\
\hline $\begin{array}{l}\text { Water spray, water mist and } \\
\text { sprinkler system }\end{array}$ & $\begin{array}{l}\text { Memastikan semua panel control dan } \\
\text { system alarm berfungsi setiap minggu } \\
\text { Pemeriksaan secara visual pompa dan } \\
\text { fitting setiap minggu } \\
\text { Pemeriksaan posisi katup pompa jika } \\
\text { tidak terkunci setiap minggu }\end{array}$ \\
\hline Sumber: DNVGL 2016 & \\
\hline
\end{tabular}

Sumber: DNVGL, 2016

EPIRB adalah radio suar untuk mengindikasikan suatu keadaan darurat yang akan dipancarkan secara otomatis (sesaat setelah EPIRB tenggalam) oleh kapal yang tenggelam ke satelit di luar bumi. Dengan EPIRB, pencairan dan pertolongan (SAR) dapat dilakukan lebih efektif pada lokasi di mana kapal karam/kandas dan sebaran atau kumpulan korban kecelakaan.

Beberapa peralatan keselamatan di atas yang harus diinformasikan kepada penumpang adalah penempatan dan cara penggunaan lifejackets, lifebuoy, alat pemadam kebakaran, tempat berkumpul (muster station) dan penunjuk arah evakuasi menuju muster station.

1. Muster station, merupakan titik yang digunakan sebagai tempat berkumpul saat terjadi kecelakaan. Penumpang berkumpul di titik tersebut untuk selanjutnya dievakuasi turun dari kapal. 
2. Safety and fire control plan. Pemilik kapal menyampaikan dokumen tersebut untuk dilakukan pemeriksaan dan pengesahan dan selanjutnya dipasang di kapal sebagai acuan dalam pemeriksaan perlengkapan keselamatan dan alat pemadam di atas kapal.

3. Safety drill. Pelaksanaan latihan keselamatan khususnya pada kapal penumpang terutama pelatihan orang meninggalkan kapal (abandon ship), sangat diwajibkan dilakukan oleh awak kapal. Selain meningkatkan kemampuan awak kapal dalam menangani kondisi darurat, sisi penumpang perlu juga untuk diberikan pemahaman secara benar tentang tindakan yang dilakukan ketika terjadi kondisi darurat.

4. Life saving plan. Gambar tersebut terlebih dahulu harus diperiksa dan disetujui oleh Direktorat Perkapalan dan Kepelautan. Pada gambar tersebut dapat memberikan informasi yang dapat digunakan dalam penentuan alat-alat keselamatan yang harus berada di atas kapal.

Beberapa ketentuan terkait dengan prosedur keselamatan di atas kapal harus diperhatikan sebagai berikut:

1. Berdasarkan ketentuan Chapter V STCW 1995, bagi awak kapal penumpang wajib memiliki keterampilan "Crowd management" dan "crisis management". Crowd management adalah suatu manajemen yang cenderung pada pengaturan massa yang melimpah atau begitu banyak, dimana awak kapal harus mampu dan terampil mengatasinya, sedangkan crowd management menjelaskan bahwa latihan yang dilakukan secara efektif akan menghasilkan pengoperasian kapal secara aman, karena dalam latihan ini akan mempelajari prosedur-prosedur keselamatan di atas kapal. Sistem manajemen ini dapat mengatasi kepanikan penumpang pada saat terjadi keadaan darurat.

2. Terkait dengan Standar Pelayanan Minimal Angkutan Penyeberangan, agar memastikan semua kapal penyeberangan mendemonstrasikan penggunaan alat keselamatan sebelum kapal berlayar, sesuai Pasal 4 Peraturan Direktur Jenderal Perhubungan Darat No.: SK.4608/AP.005/DRJD/2012.

3. Mengintensifkan komunikasi radio antara kapal penyeberangan dengan radio pantai atau dermaga sesuai Pasal 14 dan 15 Peraturan Pemerintah Nomor 5 Tahun 2010, untuk menyampaikan; Posisi kapal, kondisi pelayaran kapal dan cuaca di daerah tersebut.

\section{Metode}

Angkutan penyeberangan Bira-Pamatata dilayani dua kapal secara regular yaitu KMP. Kormomolin dan Balibo. Sementara dua kapal lainnya yaitu KMP. Sangke Pallangga dan KMP. Bontoharu tidak regular. Pada kegiatan pengabdian pada masyarakat ini, survey dilakukan di atas kapal KMP. Kormomolin. Kegiatan diawali dengan survey sistem keselamatan penumpang di atas kapal. Selanjutnya dilakukan sosialisasi prosedur keselamatan penumpang di atas kapal. Pada kegiatan survey dilakukan pendataan fasilitas keselamatan yang ada di atas kapal beserta prosedur keselamatan yang dilaksanakan. Berdasarkan hasil survey kemudian dilakukan pengeditan video keselamatan untuk menambahkan informasi yang belum tersedia.

Pada kegiatan sosialisasi, juga dilakukan pengisian kuesioner untuk mengetahui sejauh mana pengaruh pemutaran video keselamatan terhadap pemahaman penumpang terkait prosedur keselamatan di atas kapal. Kuesioner dibuat untuk memperoleh beberapa informasi terkait pemahaman penumpang pada:

1. Cara menggunakan peralatan keselamatan seperti life jacket, life buoy dan alat pemadam kebakaran.

2. Cara menemukan tempat muster station. 
| TEPAT Jurnal Teknologi Terapan untuk Pengabdian Masyarakat | Volume 3, Nomor 1, Tahun 2020

3. Cara meninggalkan kapal saat terjadi keadaan darurat.

4. Hal-hal yang boleh/tidak boleh dilakukan selama berada di atas kapal. 


\section{Hasil dan Diskusi}

\subsection{Kelengkapan Sistem Keselamatan Di Atas Kapal}

Pelaksanaan survey dilakukan di atas kapal KMP. Kormomolin. Survey dilakukan untuk mengetahui kondisi alat keselamatan di atas kapal, tanda-tanda petunjuk dan larangan serta aktifitas penumpang yang dapat mengganggu keselamatan pelayaran. Selain itu, dilakukan pengamatan cara penanganan kendaraan di atas geladak kendaraan untuk mengetahui apakah kendaraan diikat di geladak atau tidak.

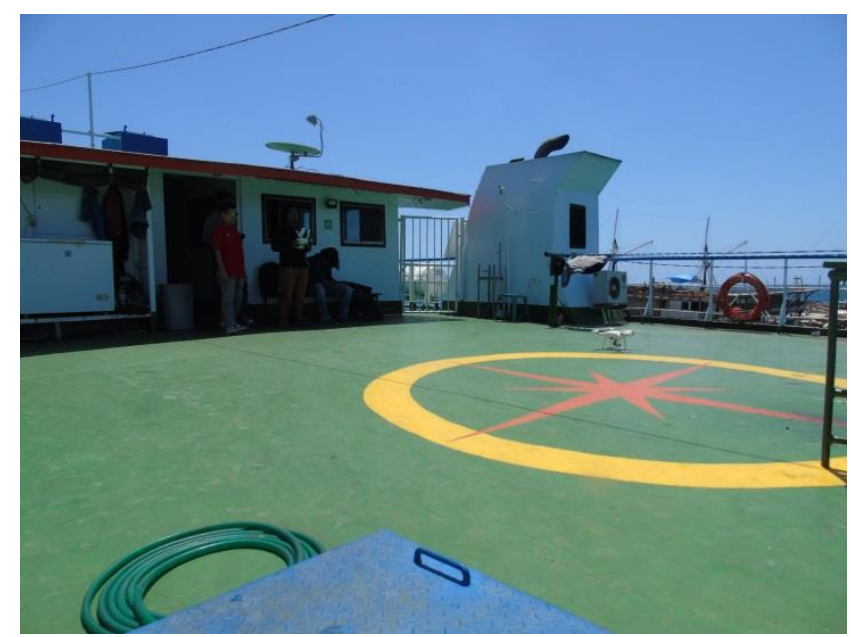

Gambar 1. Muster point di atas kapal

\subsection{Karakteristik Penumpang Di Atas Kapal}

Kuesioner yang terkumpul bersumber dari 29 orang responden. Secara umum pendidikan responden tersebar di tingkat SD sampai SLTA, namun ada satu responden yang memperoleh pendidikan di tingkat Diploma maupun Sarjana. Umumnya responden berdomisili di Selayar, namun ada juga beberapa yang berdomisili di kabupaten Bulukumba, Bantaeng, Jeneponto dan kota Makassar. Frekuensi perjalanan responden menggunakan angkutan penyeberangan bervariasi dalam dua tahun terakhir dan yang terbanyak 45\% responden adalah 1-3 kali perjalanan, selebihnya tersebar pada 4 kali sampai lebih dari 9 kali perjalanan.

\subsection{Pemahaman Penumpang terhadap Prosedur Keselamatan}

Secara umum, penumpang telah mengetahui cara penggunaan baju dan pelapung penolong Dalam pengeditan video, ditampilkan hal-hal penting yang harus dilakukan penumpang saat berada di atas kapal, diantaranya:

1. Selama pelayaran, semua penumpang berada di geladak penumpang dan kendaraan dimatikan.

2. Petunjuk cara penggunaan alat keselamatan: life jacket dan life buoy.

3. Petunjuk cara penggunaan alat pemadam kebakaran.

4. Petunjuk cara menemukan muster point dan tindakan yang harus dilakukan menuju muster point saat terjadi keadaan darurat. 
5. Petunjuk tindakan-tindakan yang boleh/tidak boleh dilakukan selama berada di atas kapal, diantaranya: merokok di tempat yang telah disediakan, tidak duduk atau berdiri di tempat yang berbahaya.

\subsection{Pengisian Kuesioner}

Khusus pada penumpang, pengisian kuesioner dilakukan dua kali, pengisian pertama dilakukan sebelum pelaksanaan sosialisasi, pengisian kedua setelah dilakukan sosialisasi.

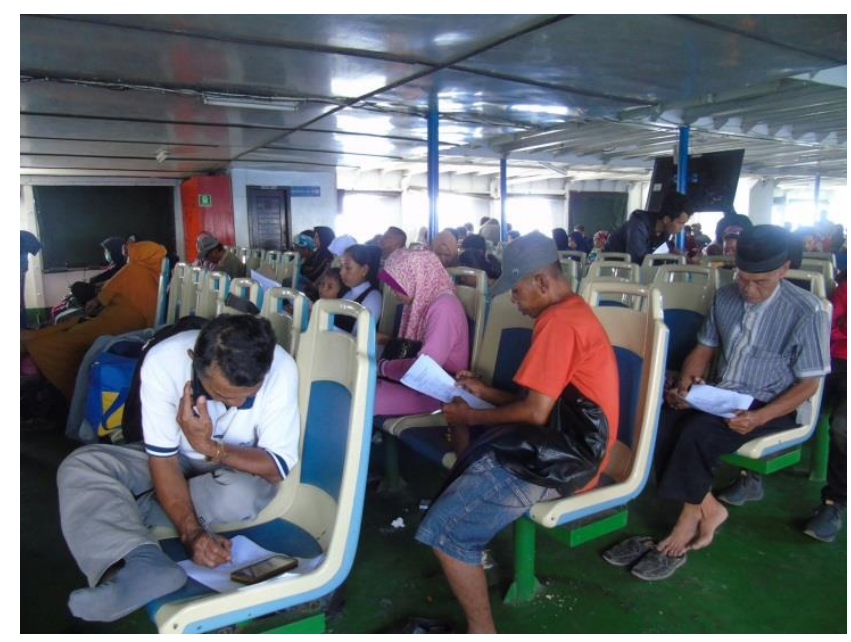

Gambar 2. Pengisian kuesioner

\subsection{Sosialisasi Keselamatan Penumpang}

Sosialisasi keselamatan penumpang dilakukan dengan memutar video petunjuk keselamatan sesaat sebelum kapal berangkat setelah dilakukan pengisian kuesioner pertama.

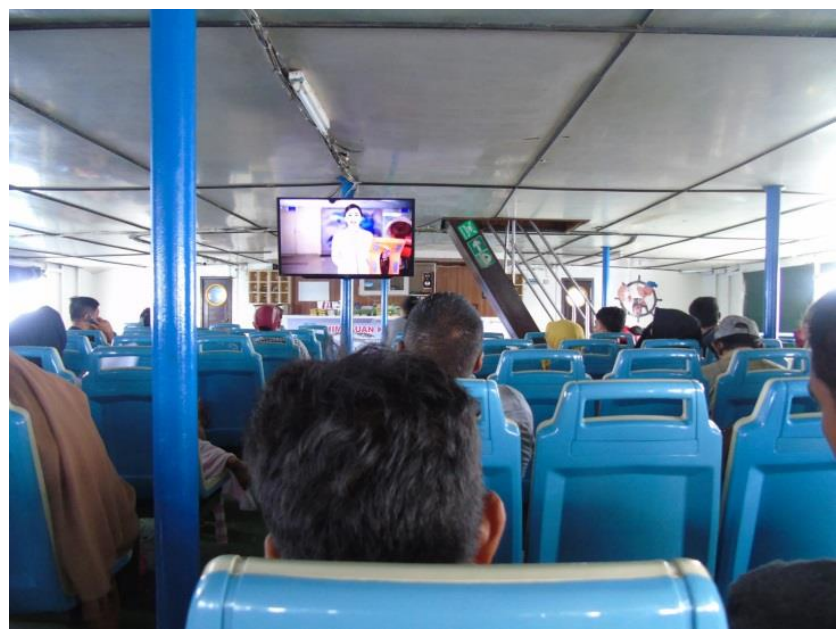

Gambar 3. Pemutaran video keselamatan

KMP. Kormomolin melayani penyeberangan Bira-Pamatata setiap harinya. Berdasarkan pemantauan di atas kapal, secara umum dapat disimpulkan bahwa kelengkapan peralatan keselamatan yang ada saat ini sudah tersedia dengan baik. Namun masih perlu dilakukan dilakukan kegiatan rutin penayangan video keselamatan sesaat setelah kapal berlayar. Pemutaran 
audio visual tidak dilaksanakan di KMP. Kormomolin dikarenakan salah satu perangkat TV mengalami kerusakan. Menurut awak kapal, kerusakan tesebut terjadi setelah adanya benturan karena ombak besar. Untuk itu sebaiknya pihak PT. ASDP melakukan perbaikan atau penggantian perangkat sehingga penayangan video keselamatan dapat dilakukan.

Dari sejumlah responden yang dikumpulkan, ada beberapa yang menyarankan untuk dilakukan peningkatan fasilitas keselamatan di atas kapal. Selain itu juga peningkatan fasilitas kebersihan. Mengenai aspek kebersihan, perlu dilakukan perhatian oleh pihak ASDP karena kebersihan terutama pada saat jumlah penumpang ramai menjadi kurang terjaga. Senada dengan penelitian yang dilakukan oleh Erlani dan Nardilla (2018), dari tiga kapal yang diteliti KMP. Bontoharu dinyatakan tidak memenuhi standar kebersihan pada saat penumpang ramai. untuk tiga angkutan penyeberangan KMP. Bontoharu, KMP. Balibo dan KMP. Sangke Pallangga. Dari ketiga kapal tersebut disimpulkan kapal ya satu responden yang menyarankan agar dilakukan peningkatan fasilitas kebersihan di atas KMP. Kormomolin. Kondisi ini juga sama pada kapal KMP. Bontoharu.

\section{Kesimpulan}

Kegiatan pengabdian masyarakat dilaksanakan di atas KMP. Kormomolin untuk memberi pemahaman kepada pengguna jasa angkutan penyeberangan Bira-Pamatata tersebut tentang sistem keselamatan dan tata cara penggunaan alat keselamatan. Kegiatan sosialisasi tersebut belum rutin dilaksanakan di atas kapal sehingga sebagian penumpang belum memahami sepenuhnya prosedur keselamatan di atas kapal. Berdasarkan hasil survey yang dilaksanakan, sosialisasi sistem keselamatan penumpang memberikan dampak positif terhadap pemahaman penumpang.

\section{Ucapan Terima Kasih}

Kegiatan ini terlaksana atas dukungan dana dari Fakultas Teknik Universitas Hasanuddin melalui Laboratory Based Education skim pengabdian kepada masyarakat. Penulis menyampaikan terima kasih kepada pihak PT. ASDP (Persero) atas izin pelaksanaan kegiatan. Secara khusus pula disampaikan terimakasih kepada awak kapal KMP. Kormomolin atas kerja sama yang baik selama kegiatan berlangsung.

\section{Daftar Pustaka}

DNVGL, (2016). Class Guideline - Maintenance of safety equipment.

Erlani dan Nardilla, T., (2018). Kondisi sanitasi kapal penumpang ferry di wilayah kerja pelabuhan Bira kec. Bonto Bahari kab. Bulukumba. Jurnal Sulolipu, Vol. 18 No. I, h. 9-14.

Faturachman, D., Muslim, M. dan Sudrajad, A., (2015). Analisis keselamatan transportasi penyeberangan laut dan antisipasi terhadap kecelakaan kapal di Merak-Bakauheni. Jurnal Teknik Mesin Untirta, Vol. I, No. 1, h. 14-21.

KNKT, (2018). Laporan Investigasi Kecelakaan Pelayaran, Miringnya Kapal Lestari. Maju (IMO 8720541) di Perairan Pabadilang Kepulauan Selayar, Sulawesi Selatan Republik Indonesia. 